\title{
Formulation and Characterization Floating Matrix Tablets of Methimazole
}

\author{
IJCRR \\ Section: Healthcare \\ ISI Impact Factor \\ (2019-20): 1.628 \\ IC Value (2019): 90.81 \\ $\operatorname{SJIF}(2020)=7.893$ \\ (c) (i) (3) \\ Copyright@IJCRR
}

\author{
Bhambar Kunal V1*, Pande Shrikant D. ${ }^{2}$, Bhambar Rajendra S. ${ }^{1}$, \\ Gadakh Pravin P.1
}

'MGV's Pharmacy College, Panchvati, Nashik, Maharashtra, India; 'Vidyabharati College of Pharmacy, Amravati, Maharashtra, India.

\section{ABSTRACT}

Introduction: Methimazole is an active pharmaceutical ingredient effectively utilized in hyperthyroidism. Methimazole inhibits peroxidase as well as iodine interactions with thyroglobulin to produce triiodothyronine with thyroxine. Methimazole shows very low protein binding (1-10\%) bounds to plasma proteins and is easily metabolized by the liver. Gastro retentive drug system improve the pharmacotherapy of the stomach by local release of therapeutic agent results in high concentrations of drug at the gastric mucosa, which further sustained for long

Aim: In this investigation, efforts were given to developing a sustained release floating matrix tablet of Methimazole.

Methodology: Floating matrix tablets of methimazole were prepared by utilizing the direct compression method. Sodium bicarbonate and citric acid were used as gas-forming agents. HPMC K100M along with Ethylcellulose used to retard drug release from the dosage form.

Result: Floating matrix tablets of methimazole were evaluated for different quality control tests to improve the quality of the product. In dissolution study of the floating matrix of methimazole formulation Floating matrix tablet (FLM4) shows maximum drug release $96.88 \%$ at the end of 12 hours while FLM-1 shows least $84.33 \%$.

Conclusion: In vitro release study of methimazole floating matrix tablets shows that polymer percentage used in the formula is enough to extend the release of the drug for at least $12 \mathrm{hr}$.

Key Words: Floating Matrix tablet, Methimazole, Sustained Release, FLM, HPMC K100M, Ethyl Cellulose

\section{INTRODUCTION ${ }^{17}$}

In a Conventional drug delivery system, periodic doses of therapeutic agents are required. Most of the drugs are formulated by conventional methods for effective drug administration, but some therapeutic agents are unstable or have narrow therapeutic ranges so require modification. These problems were overcome by developing sustained release gastro retentive drug delivery. Gastro retentive drug delivery promising approach not only retard the drug release but also retain the dosage form in the stomach. Gastro retentive drug delivery effectively improves absorption of the drug due to increased residence time in the stomach. Methimazole is absorbed through the whole Gastrointestinal tract and bioavailability are $80-95 \%$. Methimazole is a biologically active agent widely used in hyperthyroidism. It prevents iodine and peroxidase. Methimazole has a biological half-life of 5 to 6 hours so it requires three times a day dosing. Hence an attempt was made to develop floating matrix tablets of Methimazole to improve all characteristics. ${ }^{1,2,3}$

\section{MATERIAL AND METHODS}

Methimazole was purchased from Innova Laboratories, Division of Innova Remedies Pvt. Ltd. Nagpur. HPMC K100M, EC was procured from Molychem, Mumbai. All other reagents and materials were of analytical grade. ${ }^{7}$

\section{Formulation of Methimazole Floating Matrix Tablets. ${ }^{1}$}

The direct compression technique was used to formulate the Methimazole tablets for all batches containing methimazole. Sodium bicarbonate was passed through \# 36 sieves.

\section{Corresponding Author:}

Bhambar Kunal V, MGV's Pharmacy College, Panchavati, Nashik, Maharashtra, India.

Email:kunalbhambar@gmail.com

ISSN: 2231-2196 (Print) ISSN: 0975-5241 (Online)

Received: $16.05 .2021 \quad$ Revised: 02.07 .2021

Accepted: 24.08 .2021

Published: 12.09 .2021 
Magnesium stearate and Citric acid were passed through \# 60 sieves. Required quantity of drug and all other ingredients were weighed and transferred into a polythene bag and blended for 10 minutes. The blend was compressed on a 10 -station rotary press using round-shaped punches. Punches measuring $10 \mathrm{~mm}$ were used for compression of the tablets. Table1 consist of formulas for the preparation of floating matrix tablets which include Ethylcellulose, HPMC K100M and gas-forming agents like citric acid and sodium bicarbonate.

\section{Evaluation of Floating matrix tablet}

\section{a. Physical Evaluation:}

The prepared tablets were examined visually for cracks, depressions, pinholes, colour and polish. 1,2,3,8

\section{b. Size and shape:}

Vernier callipers are used for determining the thickness of the tablet.

\section{c. Test for hardness:}

Monsanto hardness tester is used for the determination of the hardness of the tablet.

\section{d) Weight variation: ${ }^{11.12,17}$}

To determine weight variation Twenty tablets were weighed individually and the average weight was calculated from the total weight of all tablets. The individual weights of tablets were compared with the average weight of tablets. The percentage difference in the weight variation should be within the permissible limits $( \pm 7.5 \%)$. The per cent deviation was calculated using the following formula.

$\%$ Deviation $=\frac{\text { Individual weight }- \text { Average weight }}{\text { Average weight }} \times 100$

\section{e) Friability test:}

Friability of the tablets was measured by using Roche friabilator. Ten tablets were weighed collectively and placed in the friabilator chamber and rotated at $25 \mathrm{rpm}$. After 100 rotations (4 minutes), the tablets were taken out from the friability and intact tablets were again weighed collectively. The permitted friability limit is $1.0 \%$. The per cent friability was determined using the following formula

$$
\text { Friability }=\frac{\left(\mathrm{W}_{1}-\mathrm{W}_{2}\right)}{\mathrm{W}_{1}} \times 100
$$

Where $\mathrm{W}_{1}=$ weight of the tablets before the test

$$
\mathrm{W}_{2}=\text { weight of the tablets after test }
$$

\section{f) Content uniformity ${ }^{13}$}

Randomly selected 20 tablets were used to calculate average weight. All tablets were crushed in a mortar and weighed accurately for analysis. In a conical flask, samples were transferred and diluted with 0 . 1NHCL. The sample content was shaken and kept for 30 minutes for the complete dissolution of the drug. After filtration dilutions were made. Drug content was estimated against blank as a reference at $\lambda_{\max } 251.5 \mathrm{~nm}$

\section{g) In Vitro Drug Release (Dissolution Studies): ${ }^{14,15,16}$}

In vitro drug release study of the samples was carried out using USP - type I dissolution apparatus (Basket type). The dissolution medium, $500 \mathrm{ml}$ of simulated gastric fluid (without enzyme), was placed into the dissolution flask maintaining the temperature of $37+0.5{ }^{\circ} \mathrm{C}$ and rpm of 100 . One Methimazole matrix tablet was placed in each basket of the dissolution apparatus. The dissolution was carried out for 12 hours. During dissolution $5 \mathrm{ml}$ sample was withdrawn after every 1 hour up to 12 hours manually. During sampling sample was filtered. The fresh dissolution medium $\left(37^{\circ} \mathrm{C}\right)$ was added every time to maintain shrink condition. Collected samples were analyzed at $251.5 \mathrm{~nm}$ using $0.1 \mathrm{~N} \mathrm{HCl}$ as blank. The cumulative percentage drug release was calculated using PCP Disso v3 software.

\section{h) In Vitro Buoyancy Study: 5,6,17}

The matrix tablet of methimazole was kept in a $100 \mathrm{ml}$ beaker containing $0.1 \mathrm{~N}$ HCL. The time required for the tablet to rise in surface and float was determined as floating lag time. The duration in which dosage form constantly remained on the surface of the medium was determined as the total floating time.

\section{i) Water Uptake Study (Determination of Swelling Index) ${ }^{6.7}$}

The swelling index of matrix tablets of methimazole was determined in distilled water at room temperature. The water uptake study of the tablet was done using the USP II dissolution apparatus. The medium used for the study was $500 \mathrm{ml}$ distilled water with a revolution of $100 \mathrm{rpm}$. The temperature of the medium was maintained at $37+0.5{ }^{0} \mathrm{C}$ throughout the study. After 12 hours the tablets were withdrawn, blotted to remove excess water and weight. The swelling characteristics of the tablets were expressed in terms of water uptake (WU) as,

$\% \mathrm{WU}=\frac{\text { Weight of the swollen tablet- Initial weight of the tablet }}{\text { The initial weight of the tablet }} \times 100$

Fourier Transform-Infra red spectroscopy (FT-IR) of Methimazole Floating Matrix Tablet:

The FT-IR spectrum of formulation FLM4 was recorded using spectrophotometer Fourier Transform-Infra red spectroscopy (Shimadzu 84005) using the KBr pellet technique. 
Differential Scanning Coulometry (DSC) of Methimazole Floating Matrix Tablet:

DSC analysis of formulation FLM4 was performed using Shimadzu-Thermal Analyzer DSC 60 on 2-5mg samples. Samples of Methimazole Floating Matrix Tablets were heated in an open aluminium pan at a rate of $10^{\circ} \mathrm{C} / \mathrm{min}$. This study was conducted over a temperature range of 30 to $300^{\circ} \mathrm{C}$ under a nitrogen flow of 2 bar pressure.

In-vitro drug release Kinetics study of Methimazole Floating Matrix Tablet: 4,5

In-vitro drug release Kinetics study of Methimazole Floating Matrix Tablet was studied using USP dissolution apparatus II and result getting by this study was analysed for different kinetic models such as zero order, first order, Higuchi, Hixson Crowell and Korsmeyer- Pappas.

\section{Optimization of Methimazole Floating Matrix Tablet: ${ }^{9,10,11}$}

\section{$2^{2}$ Factorial Design for Methimazole Floating Matrix Tablet:}

A $2^{2}$ factorial design was used in this study and 2 factors were evaluated, each at 2 levels shown in table no.7. Experimental trials were performed at all 4 possible combinations. The conc. of Ethylcellulose and HPMC K 100 M were selected as independent variables. The response \% release was selected as dependent variables. The resulting data analyzed statistically using analysis of variance (ANOVA)were fitted into Design Expert 8.0.3 software. The data were also subjected to 3-D response surface methodology to determine the influence of HPMC, Na-CMC and Avicel on dependent variables. Tablet weight was not constant because that would require the use of diluents for weight adjustment, which in turn may have caused variation in the release profile. Thus, did not alter the number of diluents in the formulation to nullify any effect due to a change in the proportion of diluents

$$
\mathrm{Y}=\mathrm{b}_{0}+\mathrm{b}_{1} \mathrm{X}_{1}+\mathrm{b}_{2} \mathrm{X}_{2}+\mathrm{b}_{3} \mathrm{X}_{1} \mathrm{X}_{2}
$$

$\mathrm{Y}$ is the dependent variable; $\mathrm{b}_{0}$ is the arithmetic mean of responses of 4 runs. $b_{i}\left(b_{1}, b_{2}, b_{3}\right.$ and $\left.b_{12}\right)$ is the estimated coefficient for the corresponding factor $\mathrm{X}_{\mathrm{i}}\left(\mathrm{X}_{1}, \mathrm{X}_{2}, \mathrm{X}_{1} \mathrm{X}_{2}\right)$ which represent the average result of changing 1 factor at the time from its low to high value. The interaction term $\left(X_{1} X_{2}\right)$ shows the response changes when 2 factors are simultaneously changed.

\section{RESULT}

\section{Organoleptic Properties:}

After evaluation floating matrix tablets were white having a smooth surface in appearance. When the variation in the drug-polymer ratio will affect. The thickness of all the formulations and ranges from 4.8-5.2 $\mathrm{mm}$. After performing the weight variation test the average percentage deviation of all the formulations was found to be less than $5 \%$. It was found that all batches show per cent drug content of more than $98 \%$. The tablet hardness of all the formulations was found in the range of $5.5-5.7 \mathrm{~kg} / \mathrm{cm}^{2}$. Another measure of tablet hardness was friability. Compressed tablets that lose less than $1 \%$ of their weight are generally considered acceptable. For all formulations tried here the weight loss was less than $1 \%$ hence acceptable shown in table no 2 . All the formulations FLM-1 to FLM-4 float in one minute but FLM4 takes minimum time as it contains the minimum amount of polymers. All the formulations FLM-1 to FLM-4 remain buoyant for more than 20 hours and lag time for floating was less than one minute shown in tables no 4 and 3 respectively. A swelling index was performed for formulation (FLM-4) shown in figure no.1. Complete swelling of the tablet takes place at the end of 10 hours after that the weight of the tablet decreases. The absorption bands shown by FLM-4 are characteristic of the groups present in the molecular structure of Methimazole. The presence of absorption bands corresponding to the functional groups present in the structure of Methimazole and the absence of any well-defined unaccountable peaks is a confirmation of the purity of the formulation shown in figure no.2. The DSC curve of Methimazole shows a sharp endothermic peak at $191.26{ }^{\circ} \mathrm{C}$ corresponding to its melting and indicating its crystalline nature shown in figure no 3. Drug release studies were performed to determine the release of the drug is slow enough for at least $12 \mathrm{hr}$ shown in figure no.4. The dissolution curve of formulation FLM4 shows maximum drug release i.e. $96.88 \%$ at the end of 12 hours while FLM1 shows the least i.e. $84.96 \%$ shown in table no.5. The value of release exponent, $\mathrm{n}$, obtained from the Korsmeyer equation was greater than 0.5 for FLM1, FLM2, FLM3and FLM4 shown in table no.6. The Model Fvalue of 73.90 implies the model is significantly shown in table no.8. Percentage release graph for $2^{2}$ factorial design and $3 \mathrm{D}$ graph response surface methodology of $\%$ release for methimazole floating matrix tablets shown in figure no 8 and 9 respectively. 3D graph of \% Desirability for methimazole floating matrix Tablets as per $2^{2}$ factorial design shown in figure no.10. Predicted Vs. actual values of \% release of methimazole floating matrix tablets shown in figure no. 11

Final Equation in Terms of Coded Factors: $\%$ release $=86.40375-0.50125 * \mathrm{~A}-2.49875^{*} \mathrm{~B}+2.85625$ $* \mathrm{~A} * \mathrm{~B}$

Final Equation in Terms of Actual Factors: $\%$ release $=344.76-2.62075^{*}$ Ethyl cellulose $-2.8205^{*}$ HPMC K100M $+0.0285625^{*}$ Ethyl cellulose* HPMC $\mathrm{K} 100 \mathrm{M}$ 


\section{DISCUSSION}

Due to the entrapment of drugs within polymers, there was a shift in melting point was observed. The highest $\mathrm{R}^{2}$ value was obtained for the Higuchi model, so diffusion was the predominant release mechanism for matrix tablets. Release exponent, $\mathrm{n}$, obtained from the Korsmeyer equation was greater than 0.5 indicate non-Fickian transport (Anamolous) so the final mechanism of drug release was swelling or chain relaxation of polymers followed by diffusion and erosion. Values of p-value less than 0.0500 indicate model terms are significant. In this case $\mathrm{B}, \mathrm{AB}$ is the significant model term. Values greater than 0.1000 indicate the model terms are not significant. Adequate Precision measures the signal to noise ratio. A ratio greater than 4 is desirable. This model shows a ratio of 20.829 indicates an adequate signal.

\section{CONCLUSION}

The general tablets parameters i.e. hardness, friability, weight variation, the thickness was found within specifications. Floating lag time was within 1 minute and the total floating time was 22 hours for all the developed formulations. For floating matrix tablets, the formulation FLM4 shows the highest drug release $96.88 \%$ as containing the minimum amount of polymers and FLM1 shows the lowest drug release $84.96 \%$ as containing the maximum amount of polymers.

\section{ACKNOWLEDGEMENT}

The Authors are thankful to Innova Laboratories, Division of Innova Remedies Pvt. Ltd. Nagpur for providing the sample of Methimazole.

\section{Conflict of Interest and Source of Funding: NIL}

\section{REFERENCES}

1. Khan F, Shaikhul M, Preparation and In-vitro Evaluation of Theophylline Loaded Gastro retentive Floating Tablets of methocel K4M. J Pharm Sci. 2008; 65-70.
2. Tanwar YS, Rana AC, Formulation and Evaluation of Famotidine Floating Tablets. Current Drug Delivery. 2007;4:51 -55.

3. Prajapati ST, Patel LD, Patel DM, Studies on Formulation and In Vitro Evaluation of Floating Matrix Tablets of Domperidone. Indian J Phar Sci. 2009; 19 -23.

4. Sungthongjeen S, Sriamornsak P, Design and evaluation of floating multi-layer coated tablets based on gas formation. Eur J Pharma Biopha. 2008;255-263.

5. Li S, Lin S, Statistical Optimization of Gastric Floating System for Oral Controlled Delivery of Calcium. AAPS Pharm Sci Tech. 20016(12):1 -12.

6. Robles LV, Martínez IJ, Sustained delivery of captopril from floating matrix tablets. Int J Pharm. 2008,36(2):37-43.

7. Shah S.H, Patel J.K, Patel N.V, In, Stomach Specific Floating Drug Delivery System A Review. Int J Pharm Tech Reas. 2009:623 -633.

8. Singh BN, Kim KH. Floating drug delivery systems: An approach to Oral Controlled Drug Delivery via Gastric Retention. J Cont Rel. 2000; 63: 235-59.

9. Scan C Sweet man, Martindale The complete drug Reference, Thirty-four edition, Published by the Pharmaceutical press, 1616-1618

10. Bhise SB, Aloorkar NH, Formulation and In-vitro Evaluation of Floating Capsules of Theophylline. Ind J Pharm Sci. 2008; 224- 227.

11. Lachman L, Liberman HA, Kanig JL, The Theory and Practice of Industrial Pharmacy, 3rd Ed., Varghese Publishing House, Bombay, 1987;416-418, 430-453.

12. Gambhire M., Ambade k., Development and In Vitro Evaluation of an oral floating matrix tablet of diltiazem hydrochloride. AAPS Pharm Sci Tech.2012; 8(3):81-87.

13. Tokumura T, Machida Y, Preparation of amoxicillin intragastric buoyant sustained-release tablets and the dissolution characteristics. J Controlled Rel. 2006; 110:581 - 586

14. Chien YW, Lin S. Effect of HPMC and Carbopol on the release and floating properties of Gastric Floating Drug Delivery System using factorial design. Int J Pharm.2003; 25(3):13-22

15. Bodmeier R, Krogel I, Floating pulsatile drug delivery systems based on coated effervescent cores. Int J Pharma. 1999;18(7):175-184

16. Rajveer Ch., Rathinaraj B.S., Design and evaluation of ketorolac tromethamine sustained release matrix tablets, Int J Curr Res Rev. 2010;2: 39-55.

17. Patil S, Jagdale S, Formulation and evaluation of xanthan gumbased floating tablet of tramadol hydrochloride. Int J Curr Reas Rev. 2012;4:171-179. 
Table 1: Formulation Methimazole Floating Matrix Tablets:

\begin{tabular}{lccccccc} 
Formulations code & Drug & Ethyl cellulose & $\begin{array}{c}\text { HPMC } \\
\text { K100M }\end{array}$ & Sodium Bicarbonate & $\begin{array}{c}\text { Citric } \\
\text { Acid }\end{array}$ & Mg-Sterate & $\begin{array}{c}\text { Total } \\
\text { weight }\end{array}$ \\
FLM1 & 15 & 100 & 100 & 30 & 13 & 2 & 260 \\
FLM2 & 15 & 100 & 80 & 30 & 13 & 2 & 240 \\
FLM $_{3}$ & 15 & 80 & 100 & 30 & 13 & 2 & 240 \\
FLM $_{4}$ & 15 & 80 & 80 & 30 & 13 & 2 & 220 \\
\hline
\end{tabular}

Table 2: Evaluation of tablets parameters

\begin{tabular}{lcccccc}
$\begin{array}{l}\text { Formulation } \\
\text { code }\end{array}$ & $\begin{array}{c}\text { Thickness } \\
(\mathbf{m m})\end{array}$ & $\begin{array}{c}\text { Diameter } \\
(\mathbf{m m})\end{array}$ & $\begin{array}{c}\text { Hardness } \\
\left(\mathbf{k g} / \mathrm{cm}^{2}\right)\end{array}$ & $\begin{array}{c}\text { Average weight } \\
(\mathbf{m g})\end{array}$ & Friability (\%) & \% Drug content \\
FLM1 & $4.8 \pm 0.21$ & 10 & $5 \cdot 5 \pm 0.65$ & $258 \pm 0.86$ & $0.91 \pm 0.12$ & $99.12 \pm 0.12$ \\
FLM2 & $5.2 \pm 0.35$ & 10 & $5.6 \pm 0.90$ & $237 \pm 0.89$ & $0.93 \pm 0.19$ & $98.36 \pm 0.18$ \\
FLM3 & $5.1 \pm 0.65$ & 10 & $5 \cdot 4 \pm 0.51$ & $238 \pm 0.73$ & $0.78 \pm 0.16$ & $98.96 \pm 0.16$ \\
FLM4 & $5.1 \pm 0.36$ & 10 & $5 \cdot 7 \pm 0.43$ & $219 \pm 0.84$ & $0.88 \pm 0.17$ & $98.74 \pm 0.13$ \\
\hline
\end{tabular}

Table 3: Determination of buoyancy lag time

\begin{tabular}{lcccc} 
Formulation Code & FLM1 & FLM2 & FLM $_{3}$ & FLM $_{4}$ \\
Time (Second) & 60 & 32 & 25 & 22 \\
\hline
\end{tabular}

Table 4: Determination of duration of buoyancy:

\begin{tabular}{lcccc} 
Formulation code & FLM1 & FLM2 & FLM & FLM $_{4}$ \\
Time (Hours) & 20 & 22 & 21 & 20 \\
\hline
\end{tabular}

Table 5: Cumulative \% Drug Released Profile of Formulation of Methimazole Floating Matrix Tablets.

\begin{tabular}{|c|c|c|c|c|}
\hline \multirow[t]{2}{*}{$\begin{array}{l}\text { Time } \\
\text { (Hours) }\end{array}$} & \multicolumn{4}{|c|}{ Cumulative \% Release (mean \pm S.D.) } \\
\hline & FLM1 & FLM2 & $\mathrm{FLM}_{3}$ & $\mathrm{FLM}_{4}$ \\
\hline 1 & $28.25 \pm 2.53$ & $30.24 \pm 3.26$ & $28.87 \pm 1.25$ & $31.83 \pm 2.36$ \\
\hline 2 & $42.90 \pm 1.53$ & $44.16 \pm 2.65$ & $42.24 \pm 1.32$ & $49.23 \pm 1.45$ \\
\hline 3 & $45.88 \pm 1.23$ & $50.00 \pm 1.56$ & $49.18 \pm 0.65$ & $54.67 \pm 1.65$ \\
\hline 4 & $53 \cdot 36 \pm 1.32$ & $57.63 \pm 1.96$ & $55 \cdot 96 \pm 0.98$ & $62.02 \pm 1.32$ \\
\hline 5 & $59.12 \pm 1.63$ & $62.92 \pm 1.98$ & $60.53 \pm 0.78$ & $68.66 \pm 1.96$ \\
\hline 6 & $65.08 \pm 0.96$ & $69.63 \pm 1.37$ & $65.22 \pm 0.74$ & $75.10 \pm 1.65$ \\
\hline 7 & $69.75 \pm 0.92$ & $73.08 \pm 1.54$ & $68.47 \pm 1.06$ & $78.78 \pm 1.24$ \\
\hline 8 & $74.80 \pm 0.34$ & $76.92 \pm 1.23$ & $72.72 \pm 0.96$ & $82.43 \pm 1.32$ \\
\hline 9 & $80.08 \pm 1.58$ & $82.06 \pm 1.32$ & $75 \cdot 27 \pm 0.68$ & $85.40 \pm 0.65$ \\
\hline 10 & $82.80 \pm 2.65$ & $84.27 \pm 0.96$ & $79.18 \pm 0.87$ & $89.24 \pm 0.54$ \\
\hline 11 & $83.32 \pm 0.59$ & $86.08 \pm .89$ & $82.08 \pm 0.85$ & $92.28 \pm 0.21$ \\
\hline 12 & $84.96 \pm 0.32$ & $89.04 \pm .48$ & $86.47 \pm 0.94$ & $96.88 \pm 0.65$ \\
\hline
\end{tabular}


Table 6: Kinetic treatment of prepared Methimazole floating matrix tablets.

\begin{tabular}{|c|c|c|c|c|c|c|}
\hline \multirow[b]{2}{*}{$\begin{array}{l}\text { Formulation } \\
\text { Code }\end{array}$} & \multicolumn{4}{|c|}{ Coefficient of determination $\left(\mathbf{r}^{2}\right)$} & \multirow[b]{2}{*}{ Korsmeyer plot } & \multirow[b]{2}{*}{$\begin{array}{l}\text { Korsmeyer plot } \mathbf{n} \\
\text { (release exponent) }\end{array}$} \\
\hline & Zero order & First order & $\begin{array}{l}\text { Higuchi } \\
\text { square root }\end{array}$ & $\begin{array}{l}\text { Hixson Crowell } \\
\text { Cube Root }\end{array}$ & & \\
\hline FLM1 & 0.8921 & 0.9503 & 0.9843 & 0.9775 & 0.9928 & 0.5017 \\
\hline FLM2 & 0.8413 & 0.9638 & 0.9804 & 0.9406 & 0.9961 & 0.5103 \\
\hline $\mathrm{FLM}_{3}$ & 0.8143 & 0.9447 & 0.9742 & 0.9456 & 0.9878 & 0.5230 \\
\hline $\mathrm{FLM}_{4}$ & 0.8143 & 0.9493 & 0.9786 & 0.9458 & 0.9969 & 0.5584 \\
\hline
\end{tabular}

Table 7: $2^{2}$ Factorial Design of Methimazole Floating Matrix Tablet:

\begin{tabular}{lcc} 
Factor & Level & Level \\
Ethyl Cellulose & $80(-)$ & $100(+)$ \\
HPMC K 100 M & $80(-)$ & $100(+)$ \\
\hline
\end{tabular}

Table 8: Analysis of Variance for \% Release of Methimazole Floating Matrix Tablet:

$\begin{array}{lcccccc}\text { Source } & \begin{array}{c}\text { Sum of } \\ \text { Squares }\end{array} & \begin{array}{c}\text { Degree of } \\ \text { Freedom }\end{array} & \begin{array}{c}\text { Mean } \\ \text { Square }\end{array} & \text { F value } & \begin{array}{c}\text { P value } \\ \text { Model Significant / Non-sig- } \\ \text { nificant Relative to Noise }\end{array} \\ \text { Model } & 117.22 & 3 & 39.075 & 73.899 & 0.0006 & \text { Significant } \\ \text { A-Ethyl cellulose } & 2.0100 & 1 & 2.0100 & 3.8013 & 0.1230 & \text { Non-significant } \\ \text { B- HPMC K10oM } & 49.950 & 1 & 49.950 & 94.465 & 0.0006 & \text { Significant } \\ \text { AB } & 65.265 & 1 & 65.265 & 123.43 & 0.0004 & \text { Significant } \\ \text { Pure Error } & 2.1150 & 4 & 0.5287 & - & - & - \\ \text { Core Total } & 119.34 & 7 & - & - & -\end{array}$

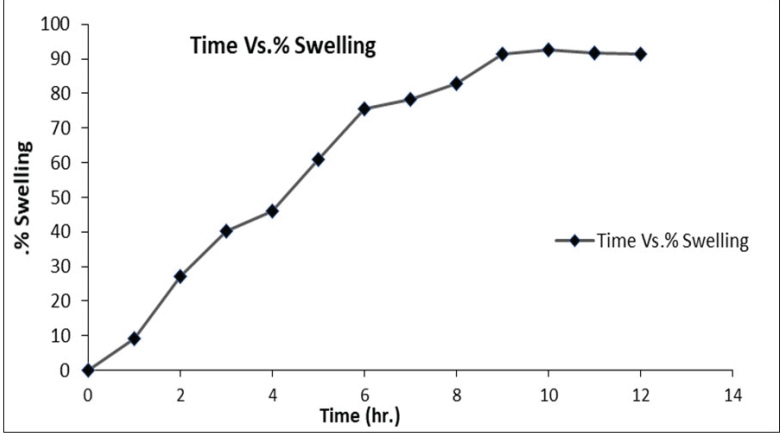

Figure 1: Swelling index of formulation (FLM4).

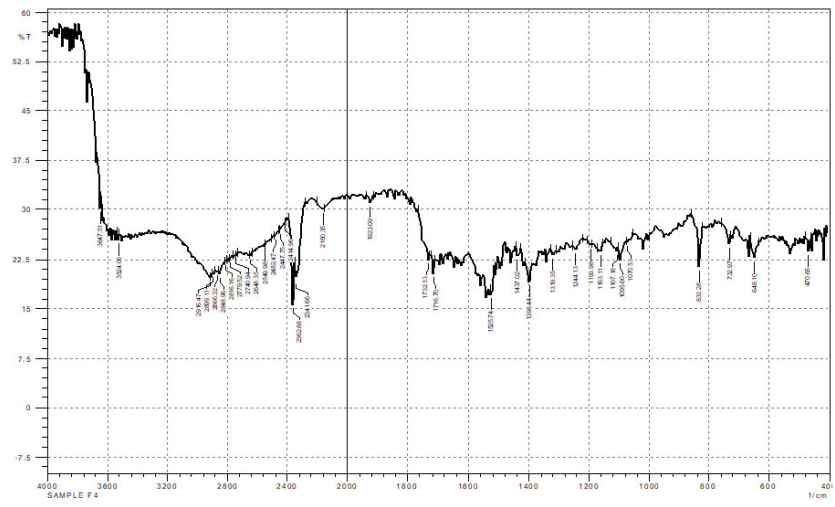

Figure 2: FT-IR of floating matrix tablet (FLM4).

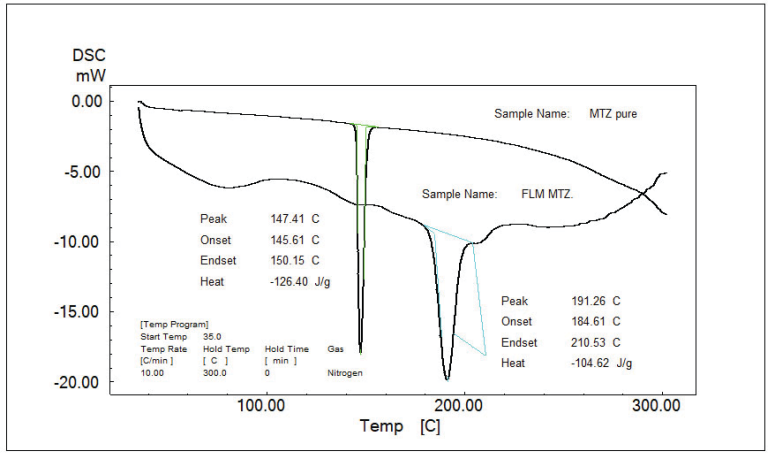

Figure 3: DSC Overlay of FLM4 and Methimazole.

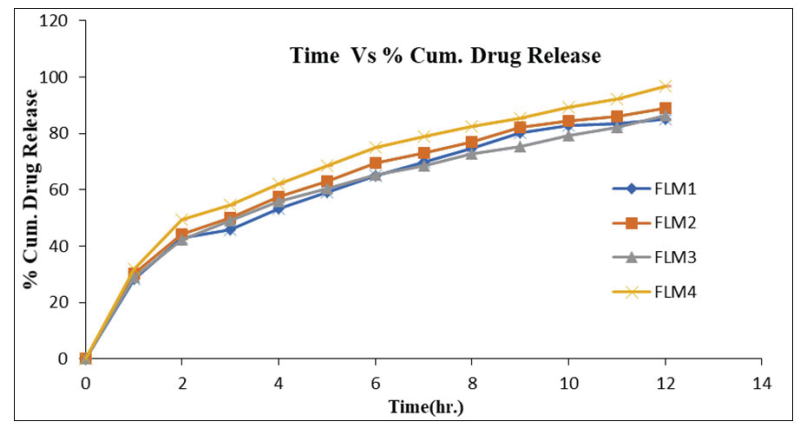

Figure 4: Methimazole Floating Matrix Tablet Combined Zero Order Graph. 


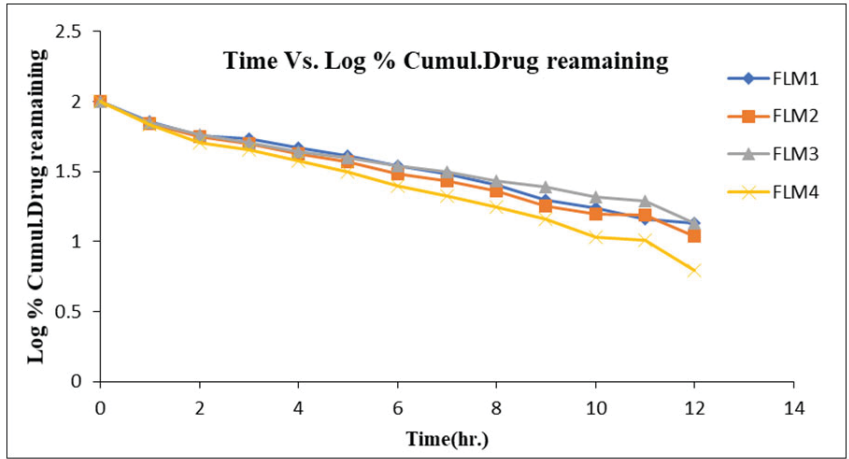

Figure 5: Methimazole Floating Matrix Tablet Combined First Order Graph.

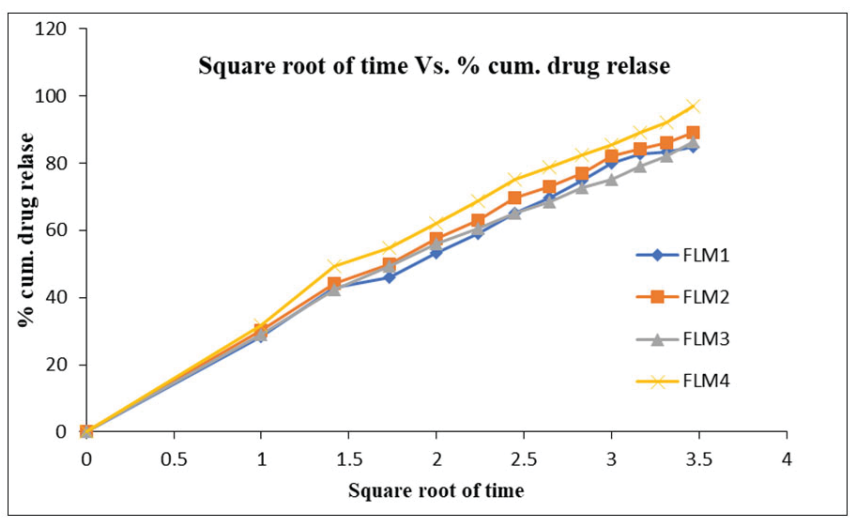

Figure 6: Methimazole Floating Matrix Tablets Combined Higuchi Graph.

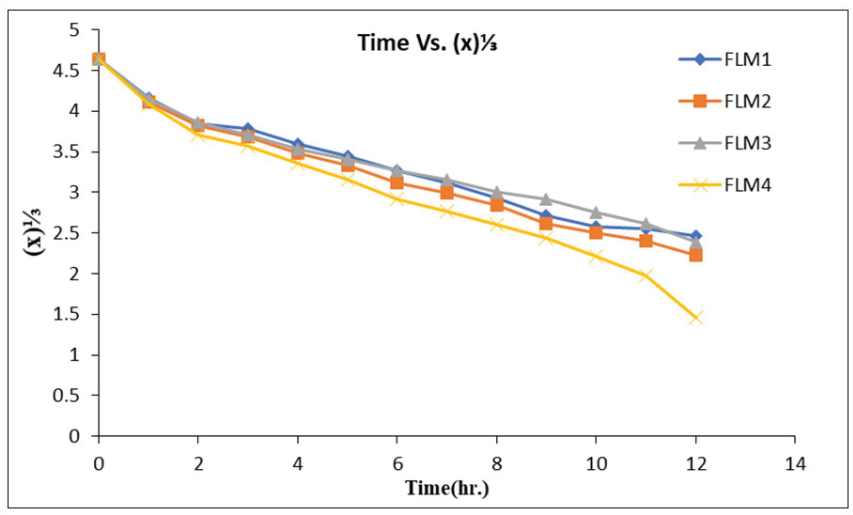

Figure 7: Hixon-Crowell Model for Methimazole Floating Matrix Tablets.

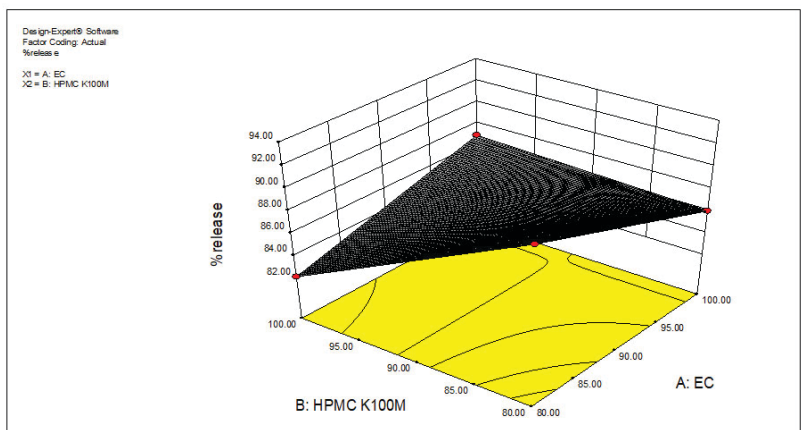

Figure 8: 3D Graph Response Surface Methodology of \% Release for Methimazole Floating Matrix Tablets as per $2^{2}$ Factorial Design.

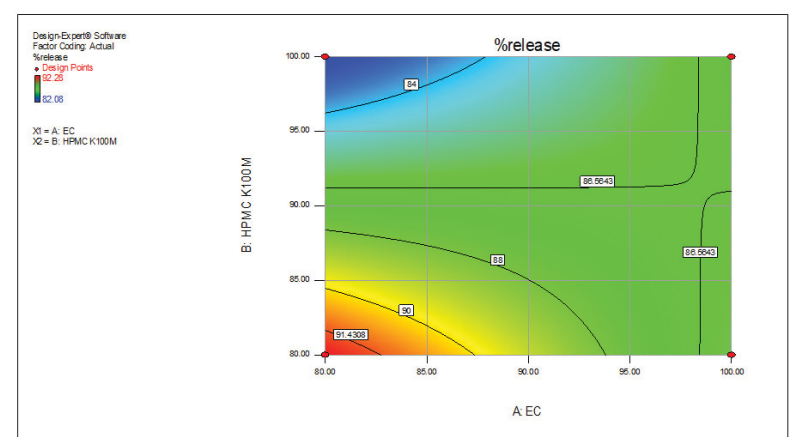

Figure 9: \% Release Graph for $2^{2}$ Factorial Design of Methimazole Floating Matrix Tablets.

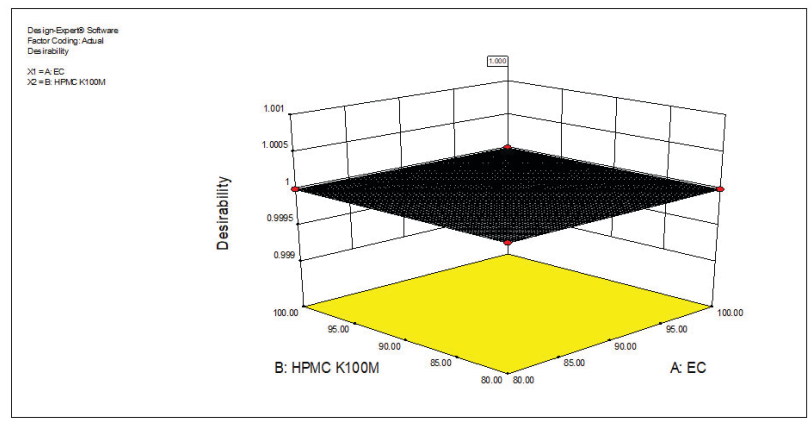

Figure 10: 3D Graph of \% Desirability for Methimazole Floating Marix Tablets as per $2^{2}$ Factorial Design.

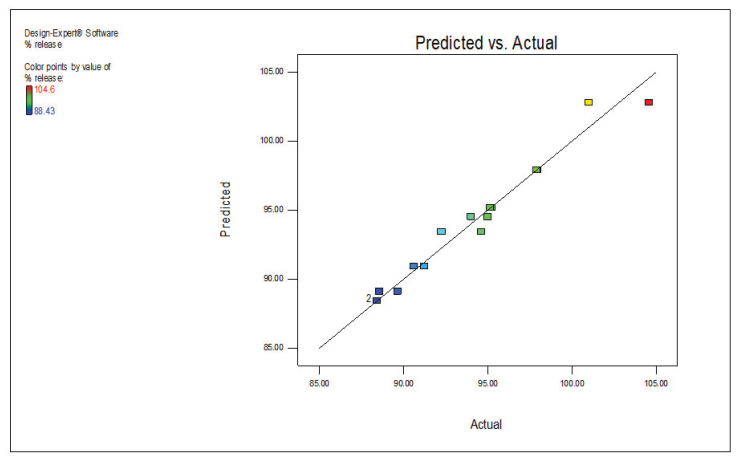

Figure 11: Predicted Vs. Actual Values of \% Release of Methimazole Floating Matrix Tablets. 